\title{
" فاعلية أساليب التقويم المستخدمة في الثانويات العربية بالعاصمة

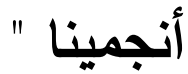

من وجهة نظر المعلمين - دراسة وصفية تحليلية

اعداد

\section{الاكتور/ عبد الهادي أحمد عبد الكريم}

مدير الثؤون الأكاديمية بجامعة أنجمينا. تثاد - وعضو هيئة التدريس بكلية العلوم التربوية

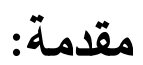

تمثل عملية القياس والتقويم جوهر العملية التعليمية ومعيارها الرئيس في معرفة القول الفصل والحكم على سير التعليم بصورة عامة، ولذا فكل من يعمل في المجال التدريسي يحتاج الى تقويم من قترة لأخرى حتى يتعرف على مستوى عمله ودرجته من الناحية العملية والتطبيقية وتحقيقه للأهداف المرسومة.

وفي ذات الصعيد تحتاج المؤسسات التعليمية الى تقويم مستمر وفقا للمراحل الدراسية، لأن لكل مرحلة أهداف وخصائص ومشكلات تختلف عن أختها، ومع أن موضوع المؤتمر هو

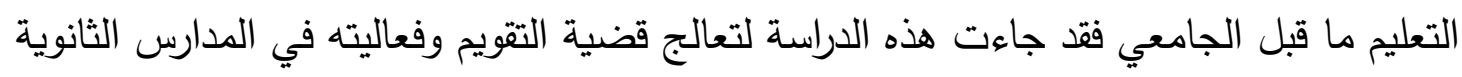
التشادية من منظور تربوي ومن وجهة نظر المعلمين الميدانيين، للعلم أن المعلم الميداني هو

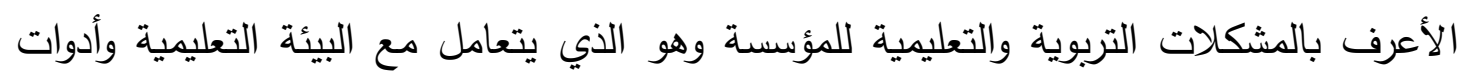

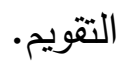

\section{مشكلة الدراسة:}

تكمن مشكلة هذا البحث في كونه يتعلق بالتقويم التربوي في المقام الأول، ثم بمرحلة

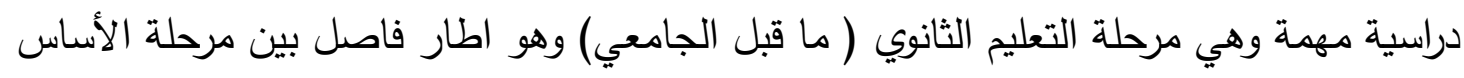
والجامعية، اذ يعالج الأساليب التقويمية التي يستخدمها المعلمون في المدارس الثانوية التشادية، وفي الوقت نفسه يوضح مدى أثر تلك الأساليب في تقويم الطلاب من الناحية المعرفية والفكرية ويبين أدوات القياس ودرجة التقييم في مختلف المواقف التعليمية داخل الفصول الدراسية. 


\section{أهمية الدراسة:}

تظهر أهية هذا العنوان في أنه يُعد من المواضع المهمة في مجال التربية بصورة عامة

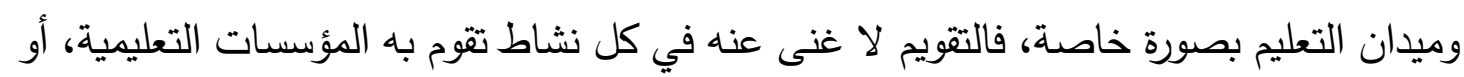
يقوم به المعلم داخل الصف أو خارجه، وان معرفة أدوات التقويم المستخدمة ومدى ملائمتها لهاطيا

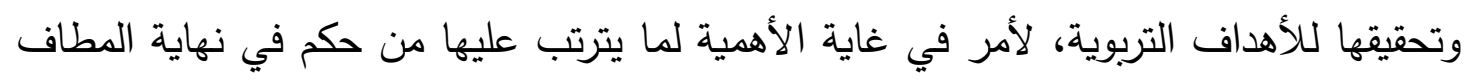

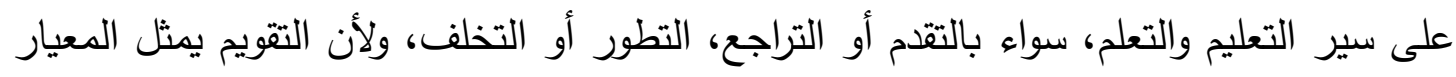

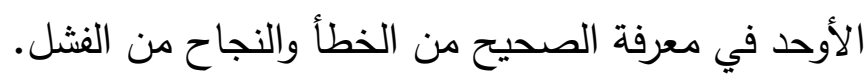

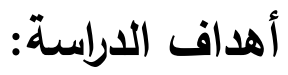

تسعى هذه الدراسة الى تحقيق الأهداف التالية:.

ا- الوقوف على المشكلات الحقيقية التي يعاني منها التقويم التربوي في الددارس الثانوية التثادية.

r- تشخيص جوانب النقص في عملية القياس والتقويم في التعليم ما قبل الجامعي.

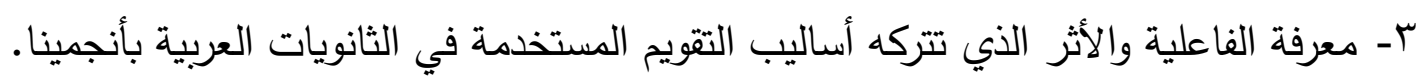

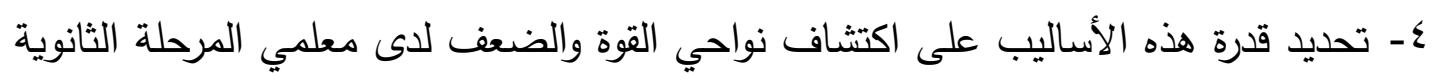

في تشاد.

0- ابراز أهمية القياس والتقويم في مجال التعليم وضروريته في جميع الأنشطة التربوية والتعليمية.

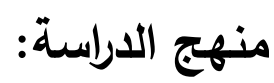

اتبع الباحث في اجراء هذا البحث المنهج الوصفي التحليلي باعتباره المنهج الأنسب

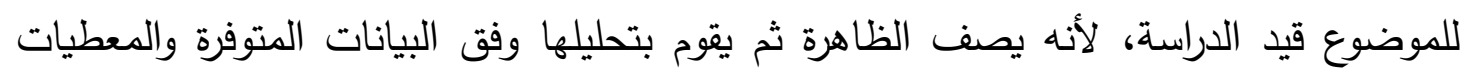

1. ـ هل لأساليب التقويم المستخدمة في المرحلة الثانوية فاعلية وأثر؟

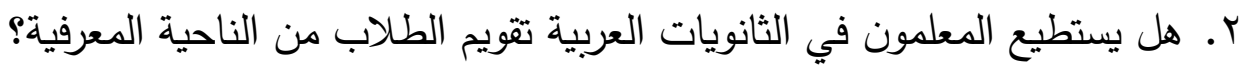

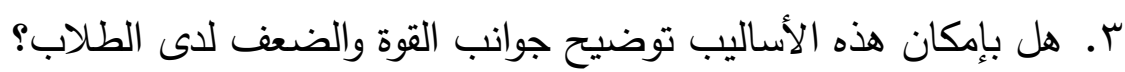

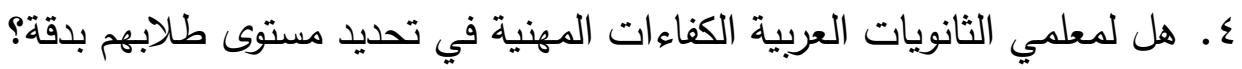
๑. هل للمعلمين خبرات كافية في اختيار الأسئلة المناسبة في الامتحانات؟ 
ا ـ لأساليب التقويم المستخدمة فاعلية كبيرة وأثر بارز • r. المعلمون في المرحلة الثانوية لهم القدرة في تقويم طلابهم. r. الأساليب المستخدمة في تقويم طلاب المرحلة الثانوية بإمكانها توضيح جوانب القوة فئرة والضعف لاى الطلاب. ع. معلمو المرحلة الثانوية لهم الكفاءات المهنية في تحديد مستويات طلابهم بدقة. ه. ليس للمعلمين الخبرات الكافية في اختيار الأسئلة المناسبة في الامتحانات.

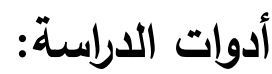

استخدم الباحث في هذه الدراسة الاستبانة كأداة رئيسية في اجراء البحث فهي الأنسب لما تتميز به من جوانب تجعلها تساعد في اعطاء نتائج حقيقية ومسلمة. حدود الدراسة:

- - الموضوعية: وتتحدد في الأساليب المستخدمة في المدارس الثانوية العربية في العاصمة أنجمينا. مصطات الاراسة:

يستخدم الباحث مجموعة من المصطلحات والمفردات سترد كثيرا في ثنايا البحث وهي

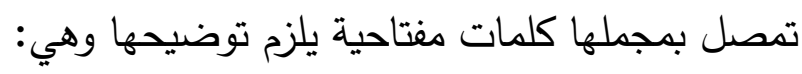

القياس: هو مجموعة من المعلومات والملاحظات الكمية عن الثيء موضع القياس ( الغربب ( ) 910

والقياس عملية تعيين أعداد لأشياء أو أحداث أو أشخاص استنادا الى قاعدة ما. (ميخائيل 990 (م) التقويم: من قوم المعوج أي عدله وأزال اعوجاجه (أنيس raV (م) وقد عرفه جرولند بقوله " عملية منهجية في تقدير مدى تحقيق الأهداف التربوية". كما عرفه باين بأنه " عملية مناط بها الوصول الى أحكام وقرارات تستخدم معطيات كمية أو وصفية " (زكرياج ( ب بم). 
التقويم هو نشاط ذهني وفني بواسطته يمكن اصدار حكم على مدى نجاح العملية التعليمية أم فثلها، ويتميز بالموضوعية والثمولية والاستمرارية. الأثر: بفتحتين ما بقي من رسم الثيء. ( الرازي 990 (م) الفاعلية: هي المخرجات التي يتركها الثيء وتظل تستمر وتتواصل وظاهر للعيان. الأسلوب: هو عبارة عن نهج خاص بالمعلم يتبعه في تقويم طلابه لمعرفة مستوى الفهم والاستيعاب

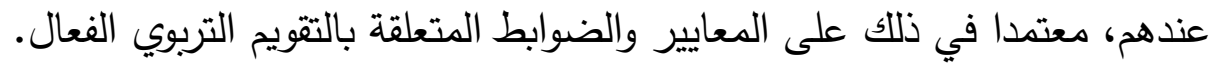
الاستخدام : هو توظيف العمليات الفكرية والقدرات الذهنية من أجل التعلم ، وهو أحد مكونات

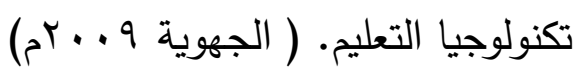

الامتحانات: عبارة عن نمط معين من أدوات القياس ووسائله يستخدمه المعلم لتحديد مستوى

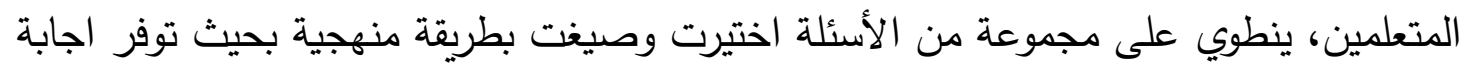

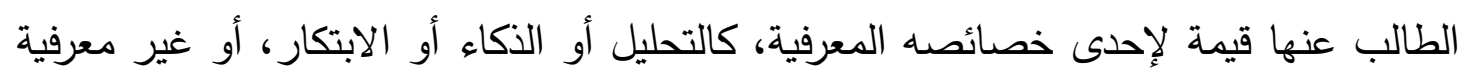
كالاتجاهات والميول والقيم.(نشواتي 997 ( ) ) المرحلة الثانوية: هي مرحلة دراسية تفصل بين الأساس والتعليم العالي، يتم فيها تكوين اتجاهات الطالب ومعارفه خلال ثلاث سنوات تمهيدا للدراسة الجامعية، ويُطلق عليها أحيانا مُسمى التعليم

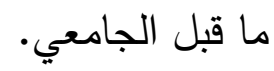

\section{الاطار النظري}

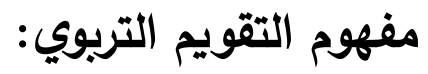

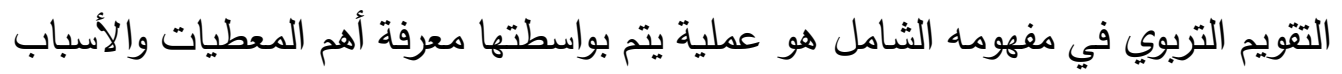
وراء النجاح أو الفشل الحاصل في التعليه، ومن خلاله يمكن الوصول الى حقدئ حقئق واقعية، وأرقام

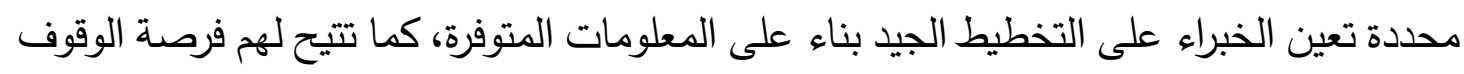

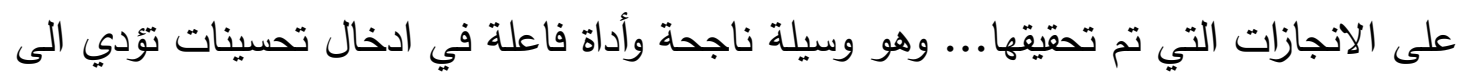
التطوير المرغوب والجودة الثاملة في ميدان التعليم.

هو عملية يتم عن طريقها تحديد قيمة معينة لشيء معين أو لحدث سلوكي معين وهو أعم وأشمل وأوسع من التقييم.(عبد الحميد محمد علي وآخرون 9 ... بم) 
وللتقويم أساليبه وأدواته التي بواسطتها يمكن قياس جوانب النمو المعرفي والمهاري والفكري في شخصية الطالب، ويستخدم في ذلك مجموعة من الأدوات القياسية مثل اختبارات التحصيل واديل التحريرية والثفوية ، المقالية والموضوعية، الملاحظة والمقابلة الثخصية والبطاقة المدرسية.(كاظم

$($ ar...)

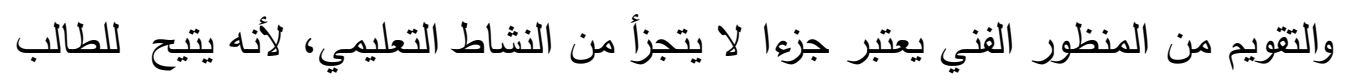

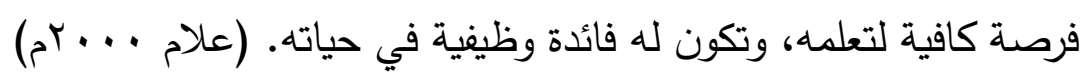
التقويم البديل:

أخذ مفهوم التقويم البديل يشق طريقه بقوة مستهديا فيما بعد بما يسمى بالنموذج السياقي،

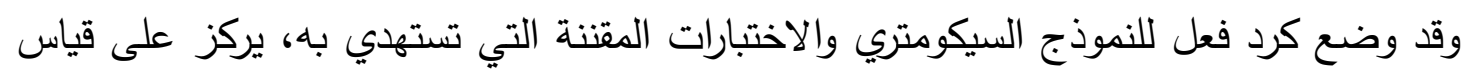
المهارات الأساسية ويهتم بالدد الأدنى من الكفايات وتحديد مستويات التعلم وعمليتي التقييم

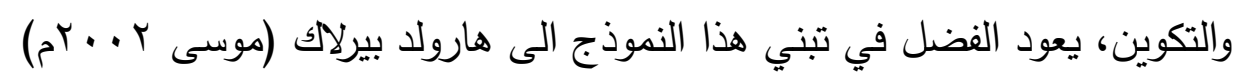

\section{خصائص التقويم البديل:}

- الواقعية: ان الموقف أو المواقف المستخدمة فيه تطابق الطرق التي بها يمكن معرفة قدرات الفرد ومهاراته في المواقف التعليمية المختلفة. - التطبيق: يجب على الطالب في اطار التقويم البديل أن يطبق المعرفة أو المهارة التي تلقاها

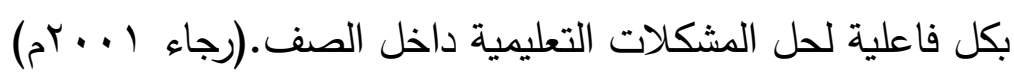

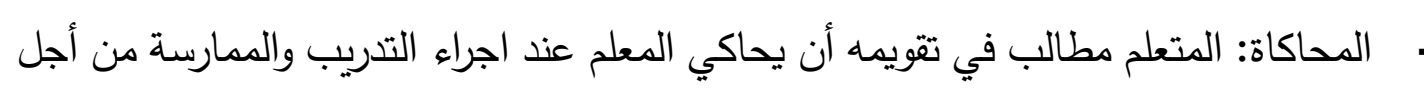
الحصول على التغذية الراجعة.

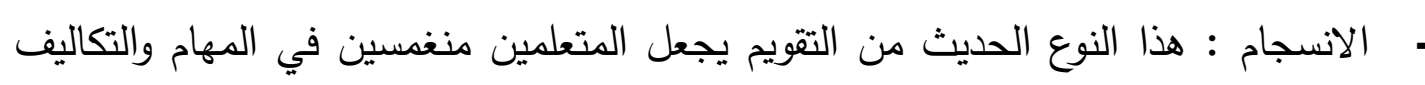

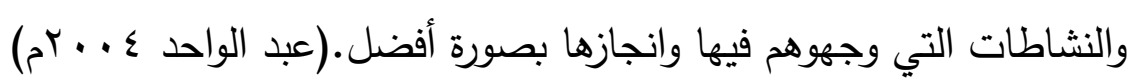

\section{التقويم و الأهداف التربوية:}

تشغل هذه الأهداف حيزا كبيرا في عملية التقويم وتعد بمثابة حلقة الوصل بين هذه العملية

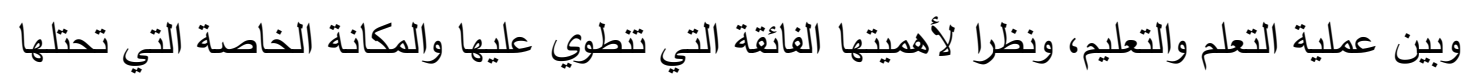

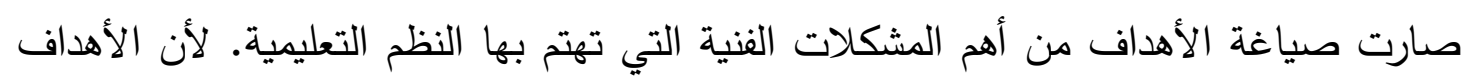

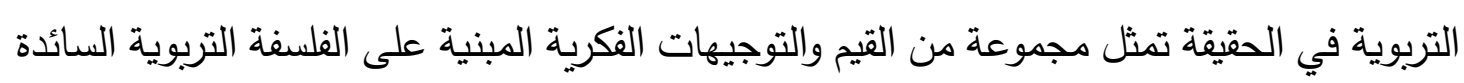
في المجتمع. وهي بالتالي تعبر عن الحاجات والمتطلبات ومعارف الدحتوى. 


\section{أنواع التقويم:}

$$
\text { ينقسم التقويم التربوي الى عدة أقسام أهمها ما يلي:. (عقل (... ام) }
$$

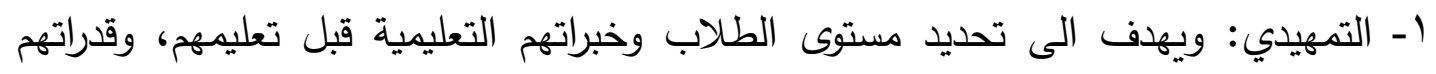

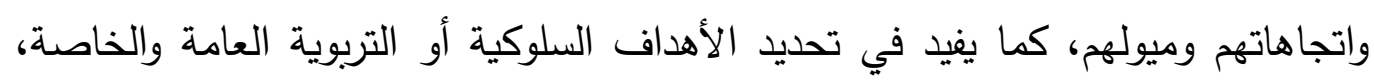
ويسمى بالتقويم القبلي.

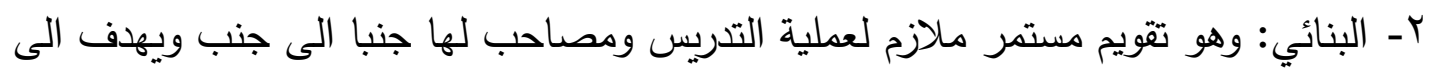
تزويد المعلم والمتعلم بنتائج الأداء بغية تحسين العملية التعليمية. ويعتمد على الاختبارات

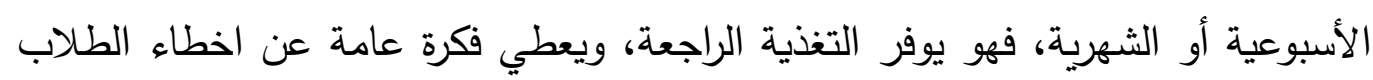
ومدى تقدمهم العلمي، ويسمى بالتقويم التكويني. r- النهائي : ويأتي في ختام البرنامج التعليمي أو السنة الدراسية، ويهتم بقياس الأهداف العامة

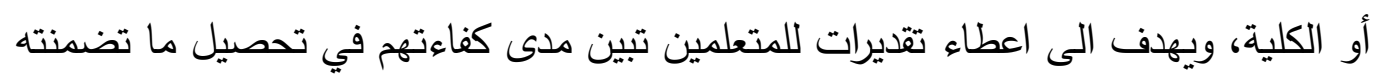

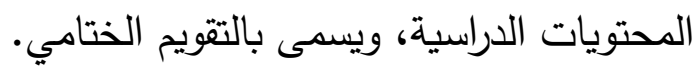

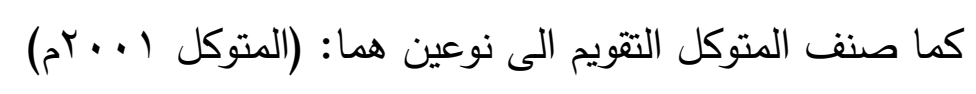

أ- داخلي: ويعنى بتقويم الفرد أو المؤسسة التربوية للأهداف بمبادرة ذاتية، وتبرز الحاجة اليه

$$
\text { بشكل واضح في التعليم المبرمج. ويسمى أحيانا بالذاتي. }
$$

ب- خارجي: ويضع في الحسبان أن خبرة ونظرة الآخرين عاملا مساعدا لتحسين وتطوير التئي التئي التعليم وتجويده حتى يصبح أكثر فاعلية، و يسمى أحيانا بالمستقبلي.

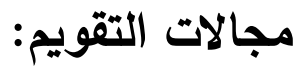

يمتد التقويم في مجال التربية ليشمل العناصر التالية:(عبد الكريم 19 • rم)

- - المتعلم: ويمثل الهرف الأساسي من العلمية التقويمية، وهنا نقوم عنده التحصيل والسلوك والفكر والنشاط والفهم والنمو بجميع أنواعه المعرفي والعقلي ...الخ.

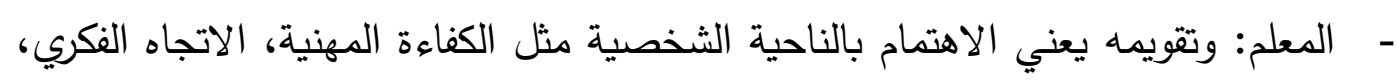

الأداء الفعلي، الثقة بالنفس، استخدام الوسائل، حل المشكلات الصفية.

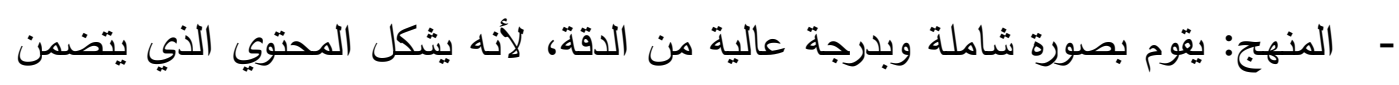
جميع المعارف التي يراد نقلها للمتعلمين. - - الطريقة: وهنا يأتي التقويم ليبين فاعلية طرائق التدريس المستخدمة وأثرها في احداث التئعين. التغيير المرغوب في السلوك، ومدى قدرتها في توصيل المعلومة. 
- الادارة: وهي المكلفة بعملية التخطيط والتنظيه، التنفيذ والمتابعة اللصيقة لسير التعليم وعليها تُوكل مهمة الاشراف والرقابة ولذا لا بد من تقويمها.

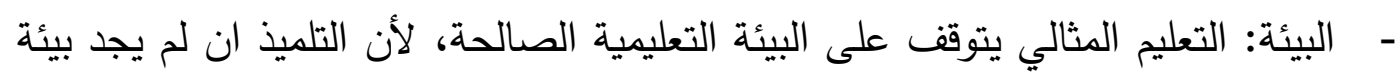
تعليمة مناسبة لا يمكنه أن يتعلم، ومن هذا المنطلق جاءت أهمية تقويم البيئة.

\section{التعليم ما قبل الجامعي في تثاد:}

يعرف هذا النوع من التعليم بالمرحلة الثانوية وقد أنثأتها دولة تثاد في الخمسينيات من القرن الماضي ضمن سلمها التعليمي الذي يضم ثلاث مراحل بهدف حل مشاكل المجتمع عبر

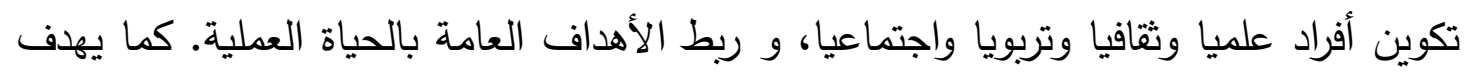

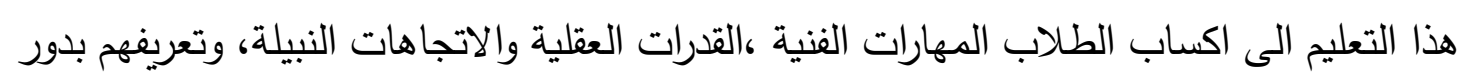

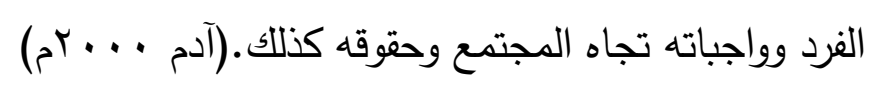

تضم هذه المرحلة أنماطا من المدراس منها الحكومية والأهلية، الفنية و التجارية الخاصة

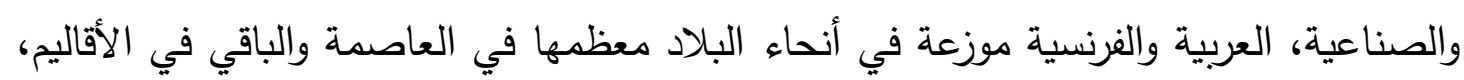

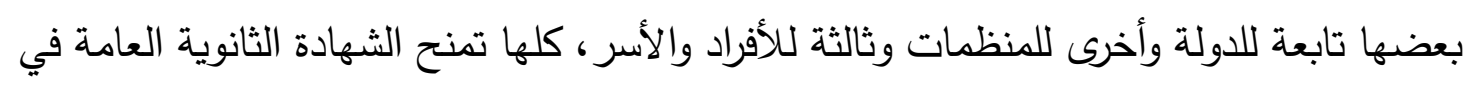

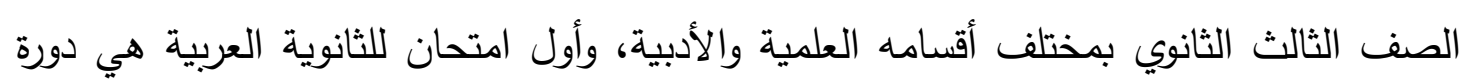
. ) $9 \wedge \mathrm{V}$

\section{أهداف المرحلة الثانوية التشادية:}

تتمحور الأهداف التي يسعي الى تحقيقها التعليم ما قبل الجامعي في تثاد حول الآتي:.

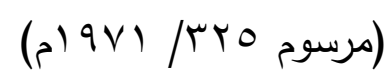

أولا: جعل الأسس التربوية منبثقة من السياسة التعليمية للدولة. ثانيا: جعل التعليم الثانوي مختبرا يشخص مشاكل المجتمع التشادي العامة والخاصة، ويعالج قضاياه ويجد لها الحلول الناجعة من منظور تربوي. ثالثا: الاهتمام بالكيف والنوع دون الكم وترقية الوعي السكاني والتثقيف الشعبي. رابعا: دعم الأفكار القيمة بتوظيف السلوك الروحي للطلاب وايجاد التوازن الفكري. خامسا: تكييف التعليم مع البيئة المحلية والواقع المعاش لمواجهة المتغيرات الراهنة. سادسا: تعليم الطلاب الاقتصاد والاستثمار وتثجيع الانتاج المحلي وزيادته. 
1. عبد الواحد محمد الجابر (r . rم) تحليل وتقويم مناهج التربية الاسلامية للصفين الأول والثاني الثانوي للمرحلة الثانوية بجمهورية تثاد.

تناولت هذه الدراسة مناهج التربية الاسلامية في الددارس العربية الثانوية وقام الباحث بتحليل

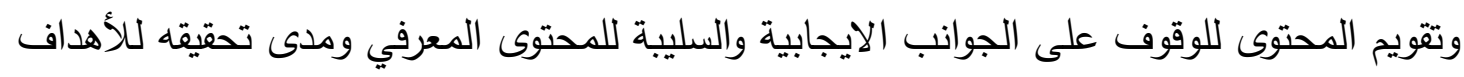
التربوية.

هدفت الدراسة الى التعرف على الطرق التدريسية والوسائل التعليمية المتبعة في توصيل

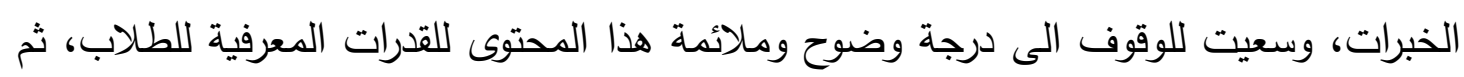

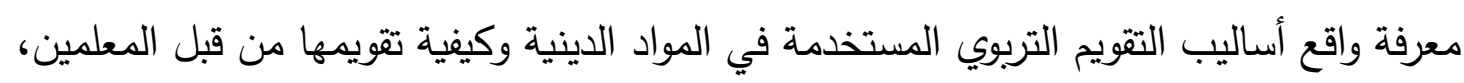

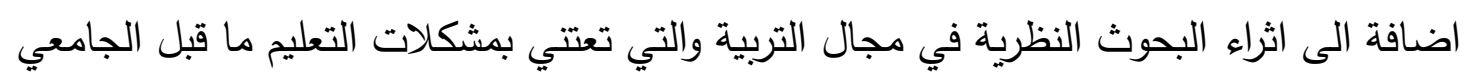
في تثاد، وأخيرا من أهدافها كذلك تطوير أساليب التقويم وتحديثها كي تساير التربية الحديثة. اتبع الباحث في دراسته المنهج الوصفي التحليلي. وتوصلت الى نتائج منها أنه لا توجد

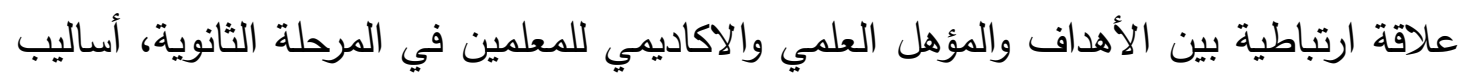

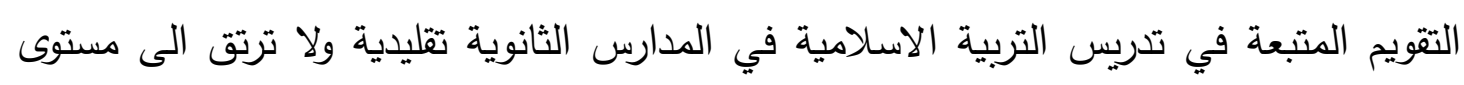

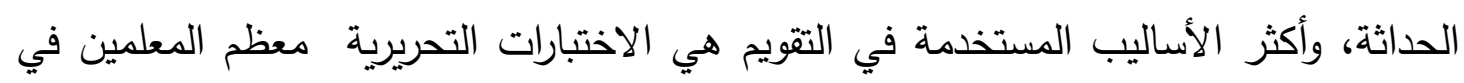
مناهج التربية الاسلامية يستعملون الطريقة الاستتباطية في التدريس. المدارس الاهلية مازالت تعتمد الإني على الحفظ والاستظهار كأفضل أسلوب للتقويم وقياس القدرات المعرفية والعقلية. أوصت الدراسة ببعض الأمور مثل الاهتمام بإعداد معلمي التربية الاسلامية في كليات

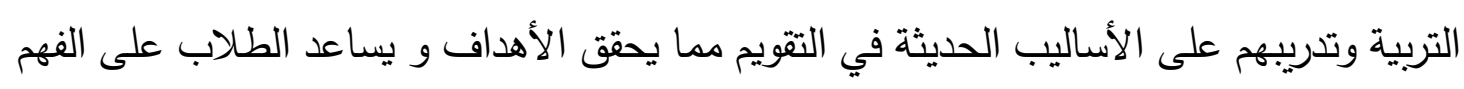

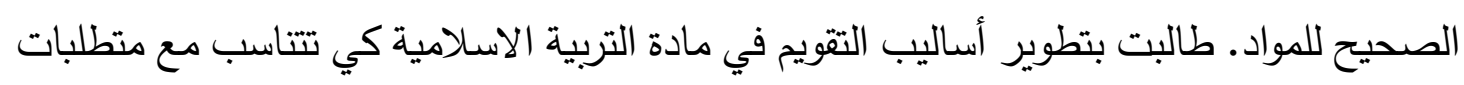

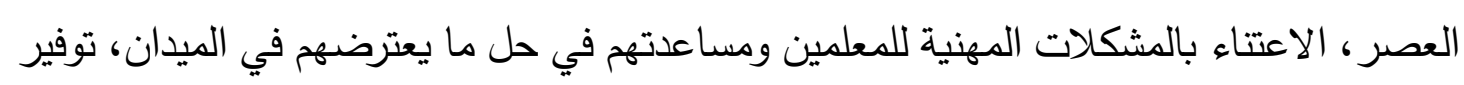

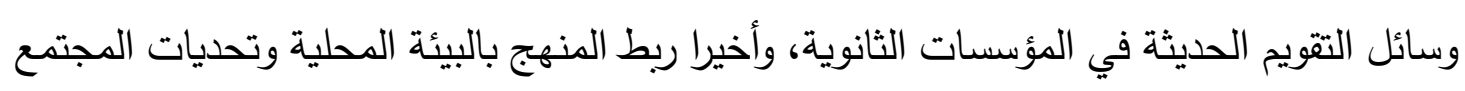
التشادي وقضايا العالم الاسلامي.

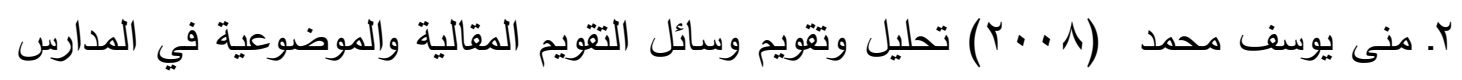


اهتمت هذه الدراسة بالامتحانات التي تجرى في مؤسسات التعليم في تثاد سيما معاهد

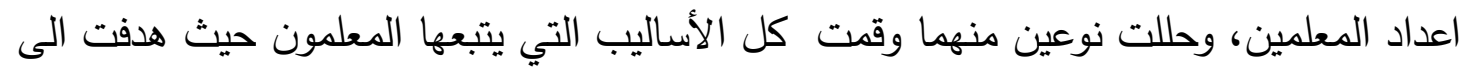
ازالة المعوقات التي تحول دون التقويم الفعلي والحقيقي الثفاف والموضوعي والذي يساعد كثيرا في تحسين التدريس وتطوير التعليم وتحقيق الأهداف التربوية.

كما توصلت الى نتائج في النهاية، وهي أن الاختبارات التحصيلية تتمثل غالبا في الدقالية وقليل من يستخدم الموضوعية باعتبارها نظام أمريكي عقيم وجاف مع الطلاب ولا يقيس قدراتهم الإني

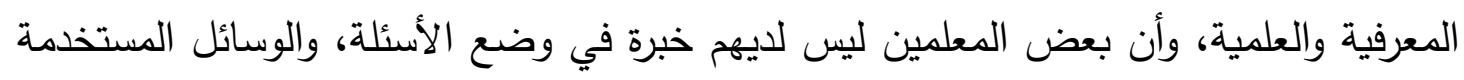

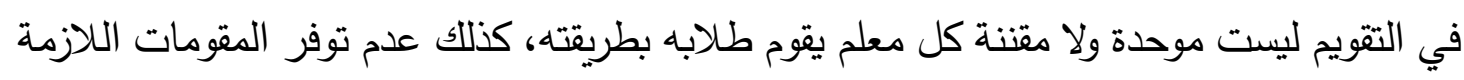
للتقويم مثل الخبرة الكافية في مجال القياس والتقويم التربوي الحديث. r. محمد رشاد زكريا: (7 ( • rم) تقويم الامتحانات المستخدمة في مرحلة الأساس بالمدراس العربية بمدينة أنجمينا دراسة وصفية تحليلية.

ركزت هذه الدراسة على واقع استخدام المعلمين لأساليب التقويم في مرحلة الأساس بمدارس

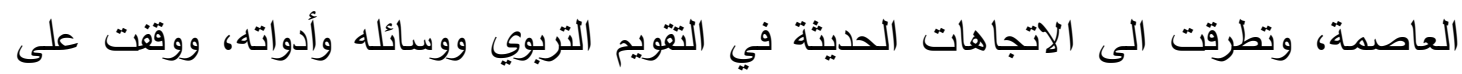

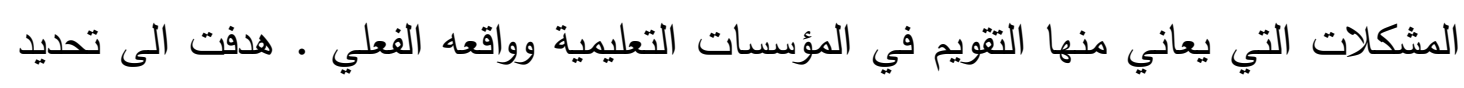
الاتجاهات الحديثة في التقويم من وجهة نظر المعلمين الميدانيين والمشرفين التربويين والمديرين في المدارس.

كما اهتمت أيضا بالشروط والمواصفات العلمية والمعايير الخاصة بالامتحانات والتي ينبغي توافرها، والمهارات الفنية اللازمة لكل معلم، وطرق التصحيح والكفايات المهنية لأعضاء هيئة التدريس في وضع الأسئلة.

اتبع الباحث في دراسته الدنهج الوصفي التحليلي وقام بتحليل البيانات والتعليق عليها، ثم استخدم الاستبانة كأداة رئيسية اضافة الى المقابلة الثخصية في جمع المعلومات.

توصلت الدراسة الى مجموعة من النتائج منها، أن الامتحانات في مرحلة الأساس لا

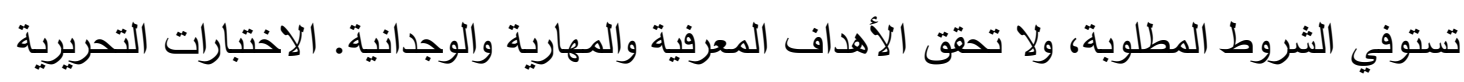

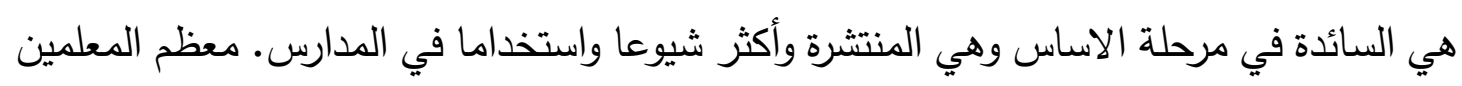
لا يجيدون أساليب التقويم التربوي الحديث بل يستخدمون الأساليب التقليدية في التقويم.

أوصت بضرورة اعادة النظر في أساليب التقويم الحالية التي تعتمد بشكل تام على التى التئل

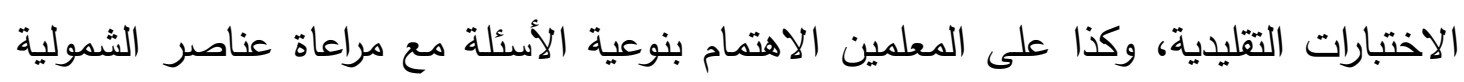


والموضوعية والتتوع الوضوح وعقد دورات تدريبية وورش عمل لهم في مجال الطرق الحديثة للتقويم،

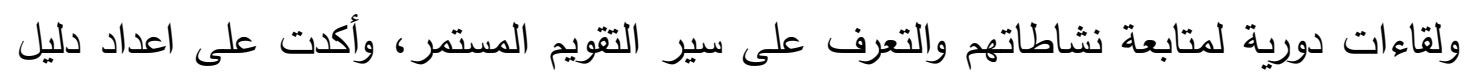

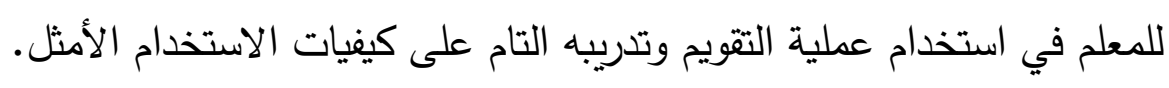

وقدمت في نهاية المطاف مقترحات تتمثل في اجراء دراسة تقويمية لأساليب التقويم المستخدمة في المدارس الثانوية العربية ( التعليم ما قبل الجامعي) لمعرفة الاشكاليات التي تواجه

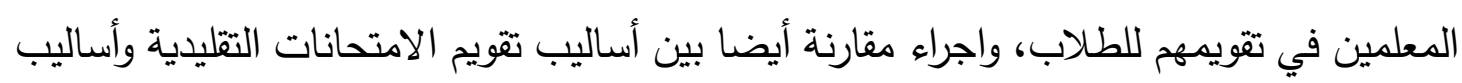
التقويم الحديثة لتوضيح الفروقات.

الاطار الميداني:

\section{أولا: اجراءات الدراسة الميدانية:}

منهج الدراسة: اتبع الباحث في دراسته المنهج الوصفي التحليلي الذي يقوم على وصف المشكلة قيد الدراسة وتحليلها وفق البيانات المتوفرة ومن ثم يعطي النتائج.

مجتمع الدراسة: يتكون المجتمع الأصلي لهذه الدراسة من معلمي المرحلة الثانوية في

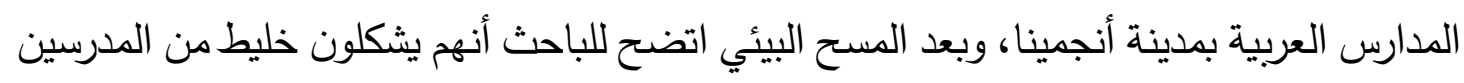

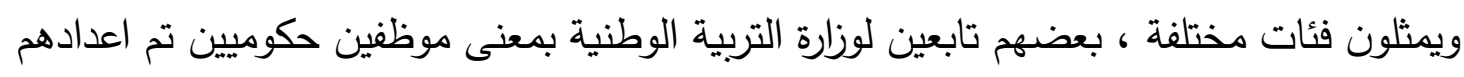

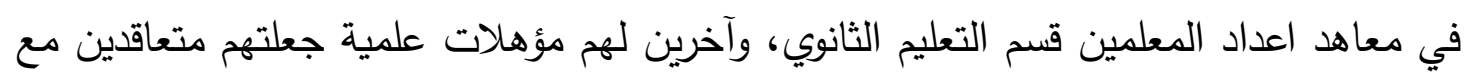
المدارس لتغطية النقص الحاصل في تدريس المواد.

يصل العدد الكلي للمعلمين في المجتمع الأصلي الى . .0 معلم ومعلمة يكونون هيئة

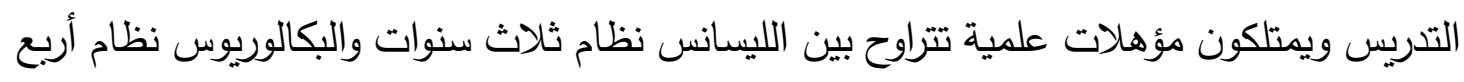

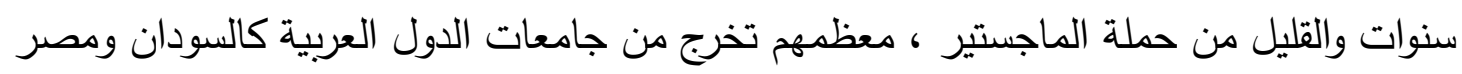
وليبيا و الجزائر والسعودية.

عينة الاراسة: جاء اختيار العينة عن طريق العينة العشوائية البسيطة، ولذا فقد أصبح مجموع عدد أفراد العينة (0.) ماكهة (0)

أدوات الداسة: ان الأداة الرئيسية التي استخدمها الباحث واعتمد عليها هي الاستبانة

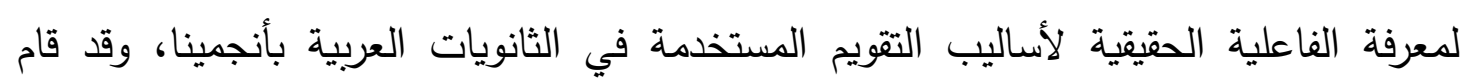

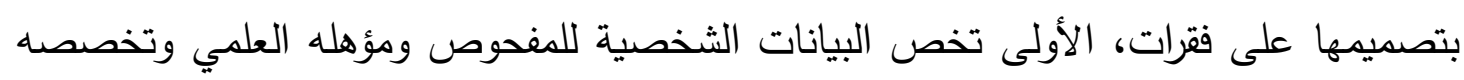
وخبرته الميدانية في التدريس وعدد الدورات التي تلقاها طيلة عمله في التدريس. أما الفقرة الثانية 
فقد كانت مخصصة للأسئلة والتي جاءت شاملة للموضوع قيد الدراسة وعددها (• ( ) أسئلة، كل سؤال يتناول جانب معين من جوانب العنوان الرئيس وله صلة مباشرة به.

وبتأثير هذه الأداة تمكن الباحث من قياس وتقويم أساليب التقويم المستخدمة في المرحلة

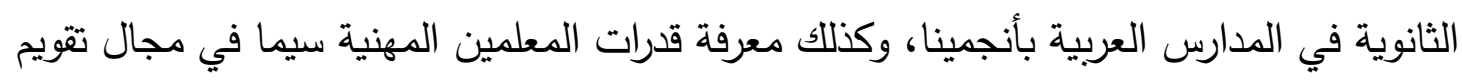

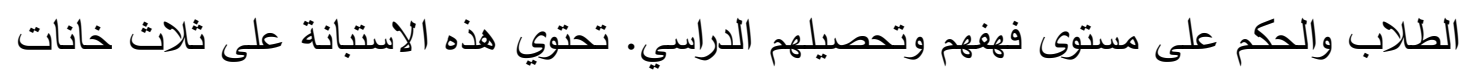

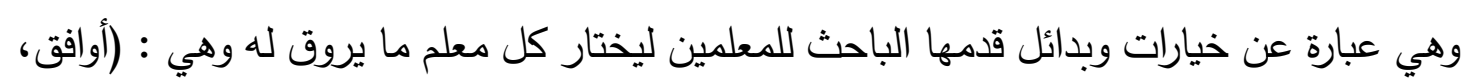

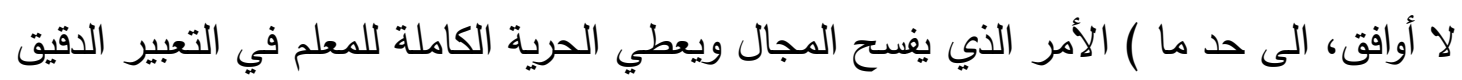
بكل حرية وموضوعية وشفافية ليضع العلامة في الخانة التي يراها مناسبة.

صدق وثبات الاستبانة: للتأكد من صدق الأداة وثباتها قام الباحث بإجراء تجربة أولية في

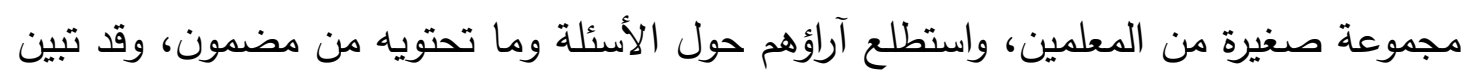

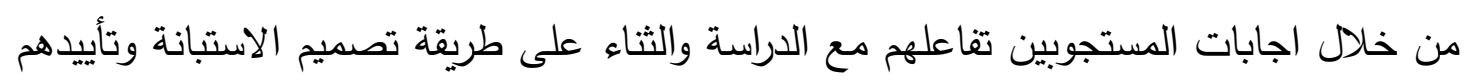
للمشروع البحثي الميداني والذي يعالج قضية مهمة وهي التقويم.

في نفس الاطار قام الباحث بتحكيم الاستبانة وعرضها على مجموعة من الخبراء التربويين

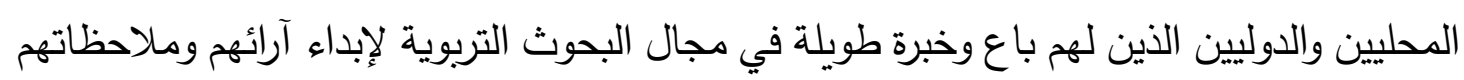

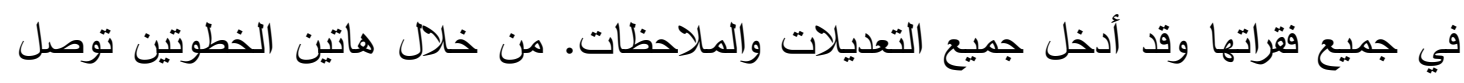

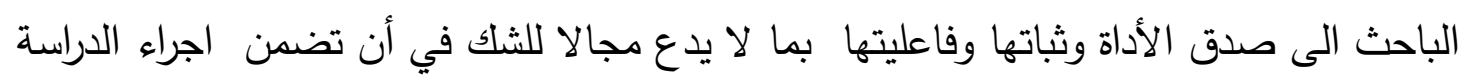
والوصول الى نتائج سليمة وواقعية مما يساعد في تحقيق الأهداف التي ترمي اليها للدراسة.

\section{ثانيا: عرض وتحليل ومناقشة نتائج الدراسة}

في هذه الجزئية سيتم التعرض لنتائج البيانات بالتحليل والمناقثة وفقا للجداول التوضيحية

جدول رقم (1) يوضح نوعية افراد العينة:

\begin{tabular}{|c|c|c|c|}
\hline المجموع & أنثى & ذكر & النوع \\
\hline 0 . & 1. & $\varepsilon$. & التكرار \\
\hline$\% 1 \ldots$ & $\% r$. & $\%$. & النسبة \\
\hline
\end{tabular}




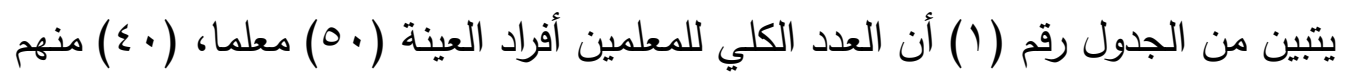

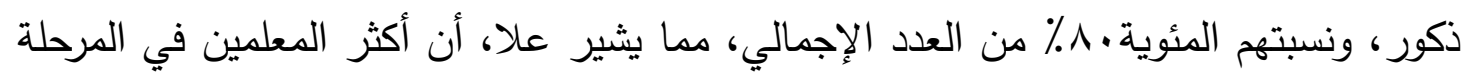
الثانوية هم رجال.

كما يتضح من التكرار أن عدد الإناث (• ( ) ويمثلن بنسبة ـ ٪ من المجموع الكلي مقارنة

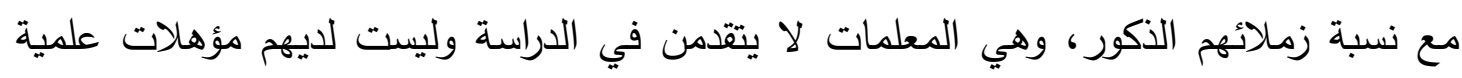
عالية.

جدول رقم (ץ): يوضح مؤهلات أفراد العينة.

\begin{tabular}{|c|c|c|c|c|}
\hline المجموع & ماجستير & بكالوريوس & ليسانس & المؤهل \\
\hline 0. & 9 & r) & $r$. & التكرار \\
\hline$\% 1 \ldots$ & $\% \wedge$ & $\% \varepsilon r$ & $\% \varepsilon$. & النسبة المئوية \\
\hline
\end{tabular}

يتضح من خلال هذه الجدول أن المعلمين في الثانويات العربية بالعاصمة أنجمينا يحملون مؤهلات علمية متباينة، فالأغلبية منهم يحملون شهادة البكالوريوس بمعنى تخرجوا من نظام الدراسة الدئ

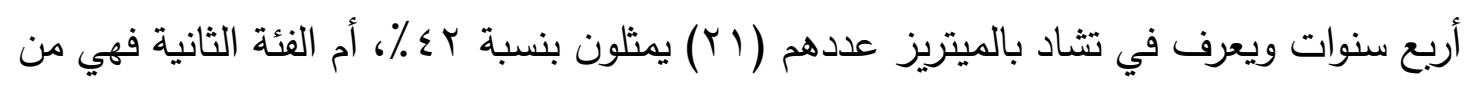

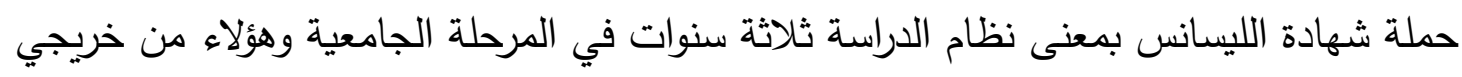

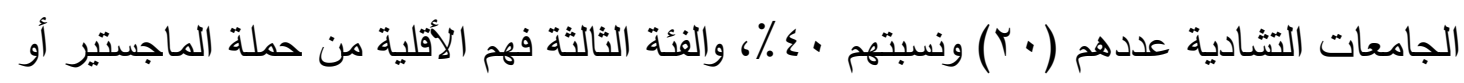

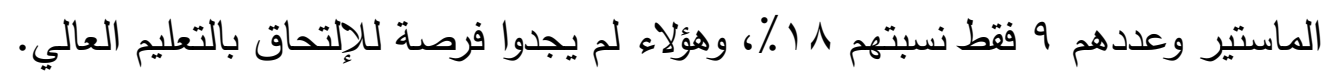

جدول رقم (ץ): يبين تخصصات أفراد العينة.

\begin{tabular}{|c|c|c|c|c|}
\hline المجموع & أخرى & علوم إنسانية & لغة عربية & التخصص \\
\hline 0. & rT & $\wedge$ & $r \cdot$ & التكرار \\
\hline$\% 1 \ldots$ & $\% \varepsilon \varepsilon$ & $\% 17$ & $\%$ \%. & النسبة المئوية \\
\hline
\end{tabular}

هذا الجدول يوضح مدى التخصصات التي تتوفر في معلمي المرحلة الثانوية بالمدارس

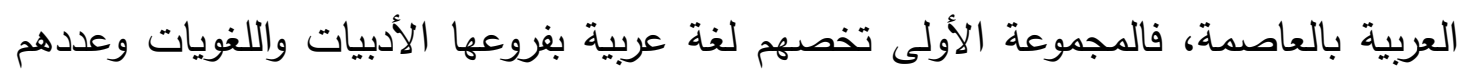

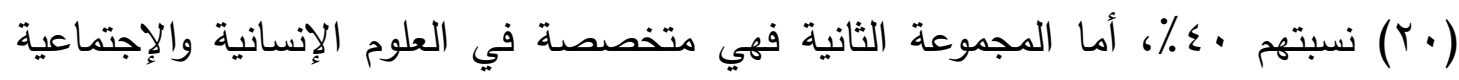

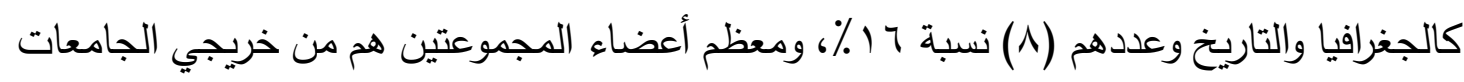
الوطنية، والمجموعة الثالثة فهم خليط من المتخصصين في الدراسات الإسلامية والمواد العلمية 
(العلوم الطبيعية) وعددهم (r) نسبتهم ؟ ؟ ٪ وهذه الفئة الأخيرة أكثرهم قد تخرجوا في جامعات

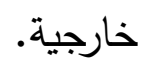

جدول رقم ( ) ): حول سنوات الخبرة لأفراد العينة.

\begin{tabular}{|c|c|c|c|c|}
\hline المجموع & ro -1 . & $1 .-0$ & $0-1$ & الخبرة \\
\hline 0 . & 1. & ro & 10 & التكرار \\
\hline$\% 1 \ldots$ & $\%$. & $\%$ & $\%$. & النسبة المئوية \\
\hline
\end{tabular}

يتبين من خلال الجدول التوضيحي أن خبرات أفراد العينة تختلف، فمنهم حديثي عهد بالتدريس ومنهم من مكث مدة لا بأس بها، وصنف آخر درس مدة طويلة تزيد عن ربع قرن، فالفئة

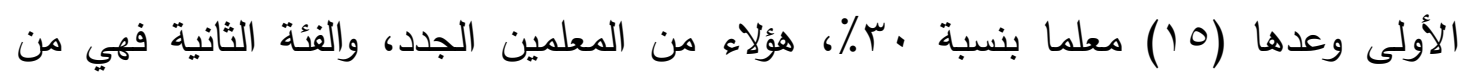

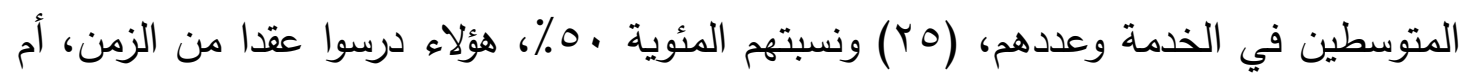

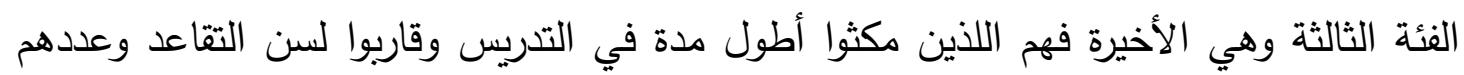

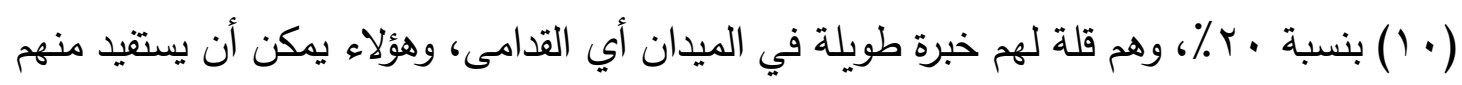
المعلمون الثباب وكذا الإدارات التعليمية.

جدول رقم (ه): يوضح عدد الدورات التدريبية التي تلقاها أفراد العينة.

\begin{tabular}{|c|c|c|c|c|}
\hline المجموع & أكثر من ثلاثة & دورتان & واحدة & الاورات \\
\hline 0 . & r & 17 & r & التكرار \\
\hline$\% 1 \ldots$ & $\%$ \% & r & $\% \varepsilon$ & النسبة المئوية \\
\hline
\end{tabular}

يتضح من خلال هذا الجدول أن المعلمين في الميدان تلقوا دورات تدريبية بأعداد مختلفة نسبة لظروفهم الخاصة والفرص المتاحة، فمنهم من تلقى دورة واحدة فقط طيلة عمله في التدريس

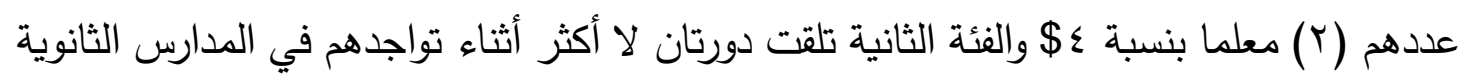

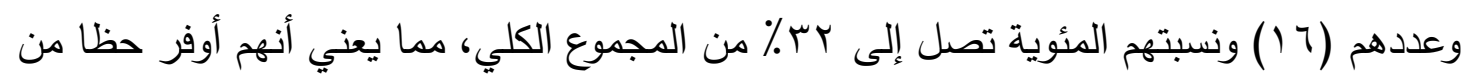

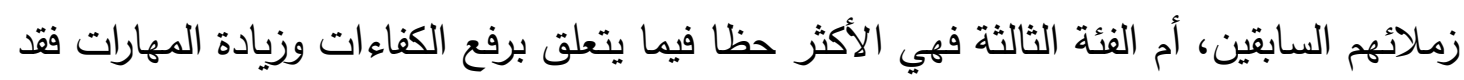

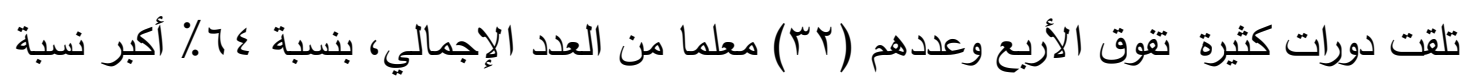

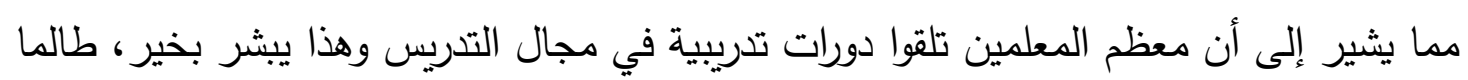
أن المعلمين شاركوا في الدورات التأهيلية التي ترفع من كفاء اتهم المهنية. 
جدول يوضح أسئلة الاستبانة

\begin{tabular}{|c|c|c|c|c|c|c|c|c|}
\hline \multirow{2}{*}{ 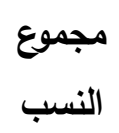 } & \multicolumn{2}{|c|}{ لا أوافق } & \multicolumn{2}{|c|}{ إلى حد ما } & \multicolumn{2}{|c|}{ أوافق } & \multirow{2}{*}{ 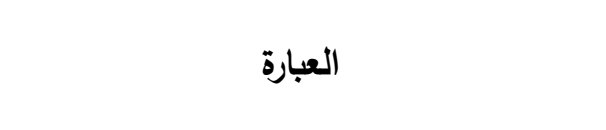 } & \multirow{2}{*}{ 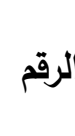 } \\
\hline & النسبة & العدد العد & النسبة & العدد الع & النسبة & 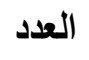 & & \\
\hline$\% 1 \ldots$ & $\% \varepsilon$ & $r$. & $\%$ & ro & $\% 1$. & 0 & أساليب التقويم المستخدمة في الثانويات حديثة & 1 \\
\hline$\% 1 \ldots$ & $\%$ ir & 7 & $\%$. & $r$. & $\%$ $\uparrow$ & $r \varepsilon$ & تساهم في معرفة اتجاهات الطلاب وتحديد & r \\
\hline$\% 1 \ldots$ & $\%$ \% & $1 \varepsilon$ & $\% \leqslant 7$ & r & $\%$ Y & r & توفر معلومات مهمة للإدارة المدرسية & r \\
\hline $1 \ldots 0$ & $\%$ & 1. & $\%$. & ro & $\%$ & 10 & تبين نقاط الضعف والقوة في المحتوى الدراسي & $\varepsilon$ \\
\hline$\% 1 \ldots$ & $\% r r$ & 11 & $\% r$ & 17 & $\% \leqslant 7$ & r & تساعد على نفهم مشكلات الطلاب المعرفية & 0 \\
\hline$\% 1 \ldots$ & $\% 11$ & 9 & $\%$ r & 11 & $\%$ \% & rr & نعطي خلفية دقيقة عن المستوى الحقيقي & 7 \\
\hline$\% 1 \ldots$ & $\% 1 r$ & 7 & $\%$. & rv & $\% \longleftarrow \varepsilon$ & iv & تقيس قدرات الطلاب الاستيعابية مهاراتهم & v \\
\hline$\% 1 \ldots$ & $\%$ & 0 & $\%$. & $r V$ & ד & 11 & تقيم اراء المعلمين المهني ومدى توصيلهم & $\wedge$ \\
\hline$\% 1 \ldots$ & $\% r r$ & 11 & $\% 07$ & rA & \%rr & 11 & تعين على التخطيط الجيد وتوجيه الطلاب نحو & 9 \\
\hline$\% 1 \ldots$ & $\% \curlyvee \wedge$ & $1 \varepsilon$ & $\%$. & $r$. & $\%$ & 7 & تربط بين الجوانب النظرية والتطبيقية للعملية & 1. \\
\hline
\end{tabular}


1- أجابت المجموعة الأولى على هذا السؤال الأول بالموافقة وعددها(0) معلم ونسبتهم المئوية

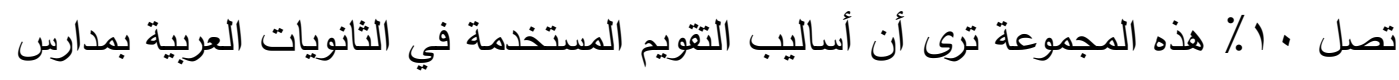

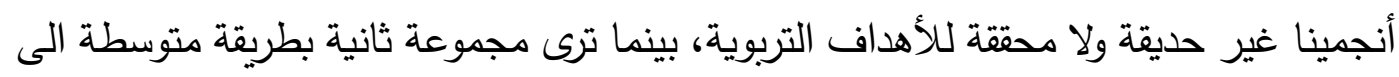

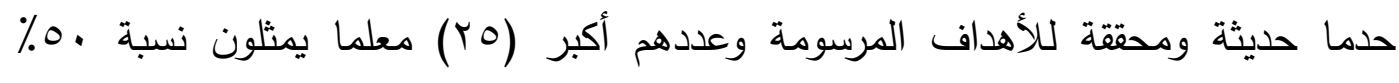
والمجموعة الثالثة خالفت سابقاتها وأصرت على أن أساليب التقويم حديثة وملائمة ومحققة لإنة

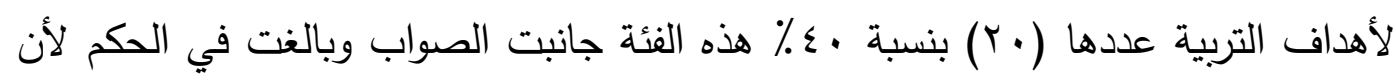
الواقع هو بخلاف ذللك.

r-وافق عدد كبير من المفحوصين في هذا السؤال المتعلق بمساهمة أساليب التقويم في معرفة

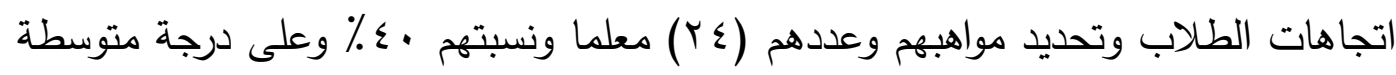

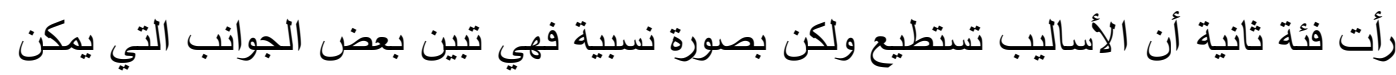

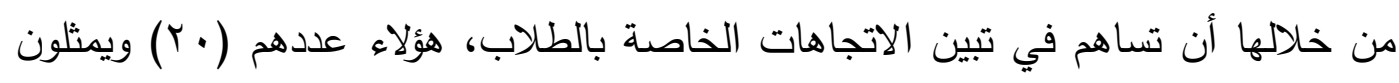

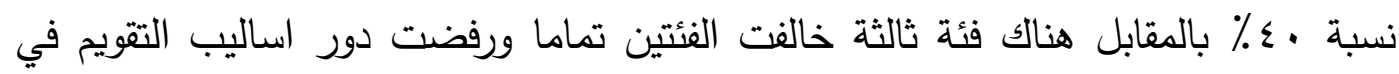

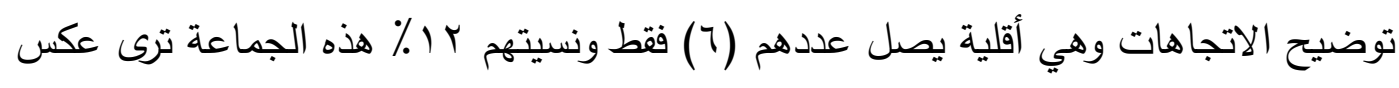
ما رأته المجموعتين الأولى والثانية.

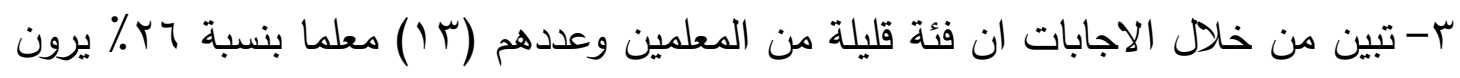

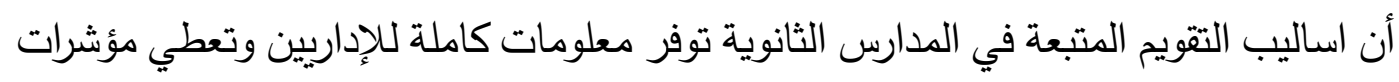

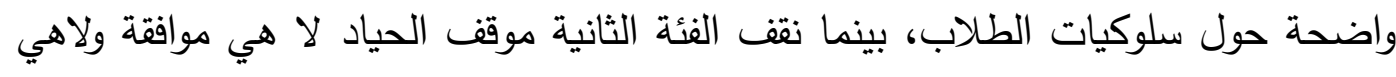

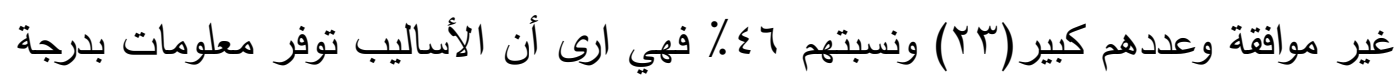

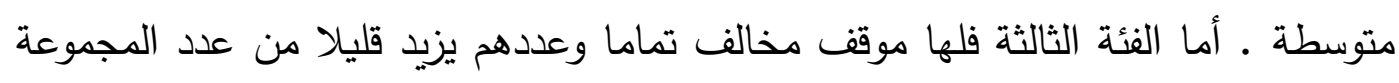

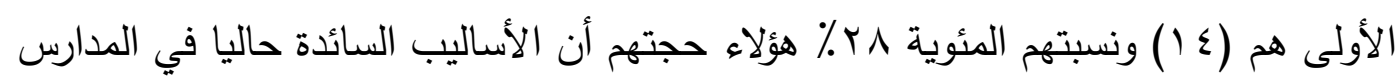

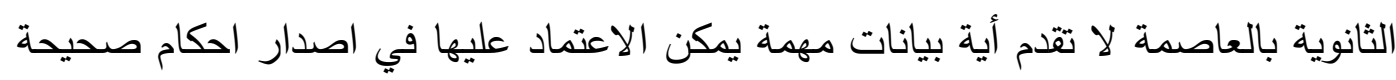

$$
\text { وقرارات صائبة. }
$$

ع- أوضح أفراد المجموعة الاولى أن أساليب التقويم المستخدمة في الثانويات العربية التثادية

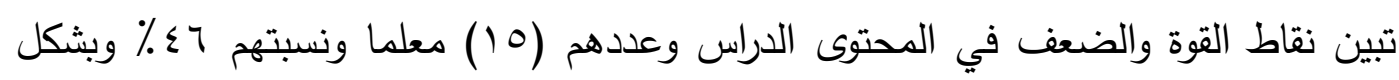

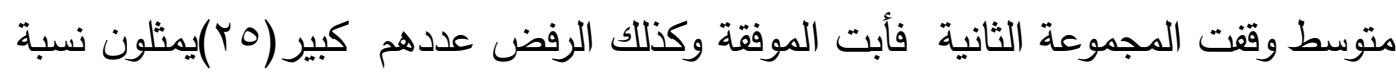

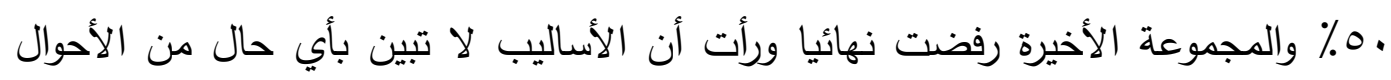

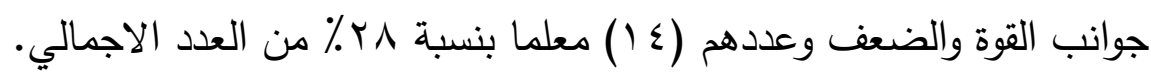

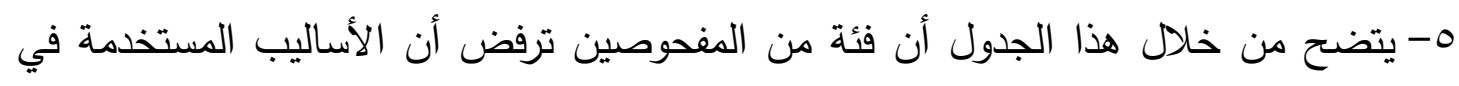

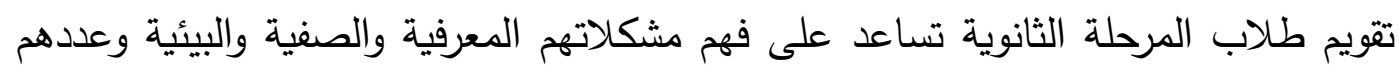

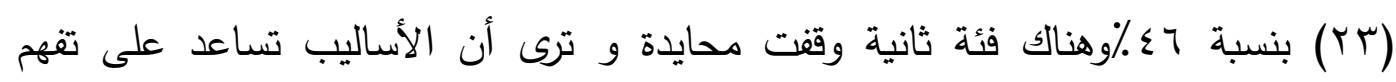


المشكلات بدرجة متوسطة وعددهم (T (1) معلما ونسبتهم rr\%٪. على النقيض تماما رفضت الفئة الثالثة الموافقة وأصرت على أن الأساليب لا تساعد بشكل مطلق وعددهم(1) (1) معلما وتصل نسبتهم المئوية بr \% من العدد الاجمالي.

1- وافقت مجموعة لابأس بها في هذا السؤال وأكدت أن الأساليب التقويمية في الثانويات تعطي لإلي

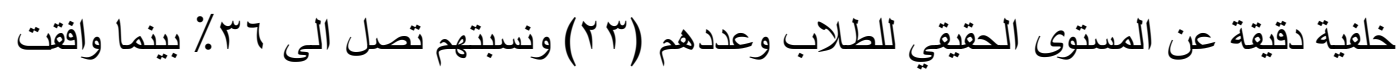

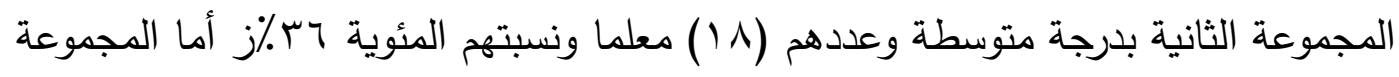

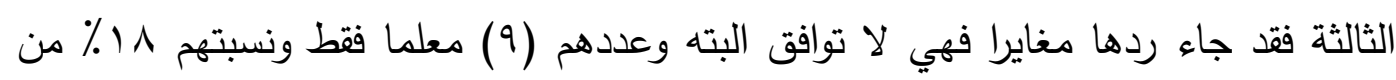
العدد الكلي للعينة. V- اتضح من خلال اجابات الفئة الاولى للسؤال أن الأساليب تقيس قدرات الطلاب الاستيعابية

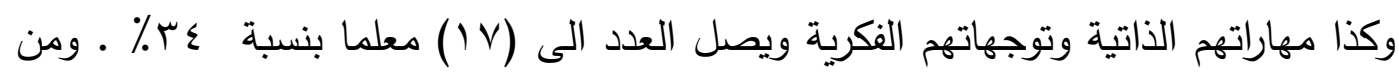

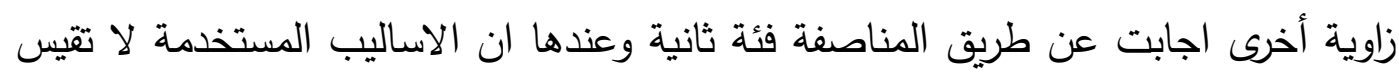

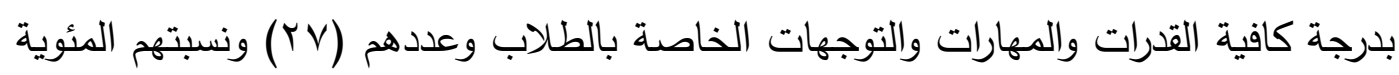

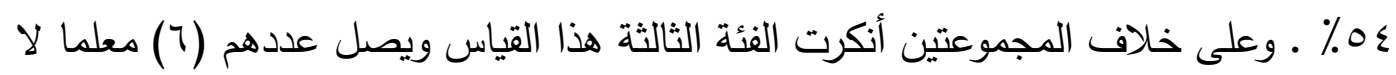

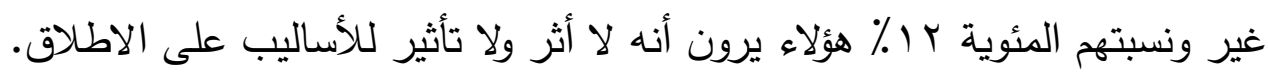

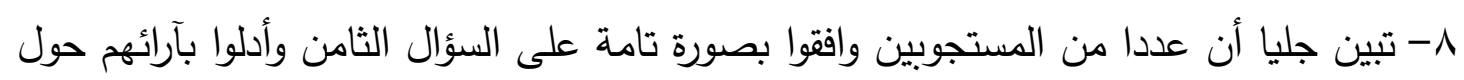
قضية تقييم الأداء المني للمعلمين ومدى توصيلهم للمعلومات على الوجه الأكمل، عدد هؤلاء

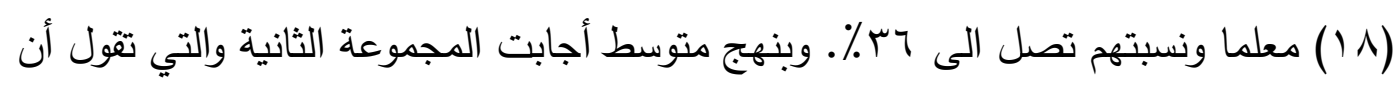

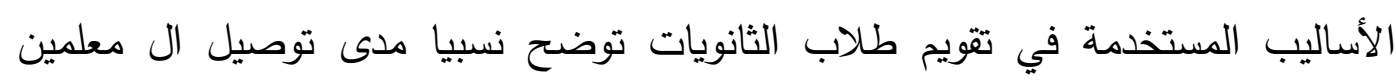

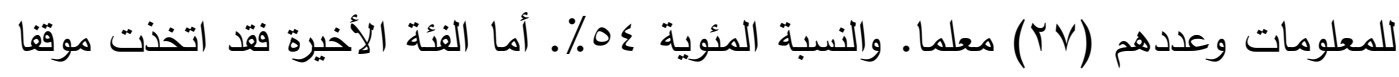

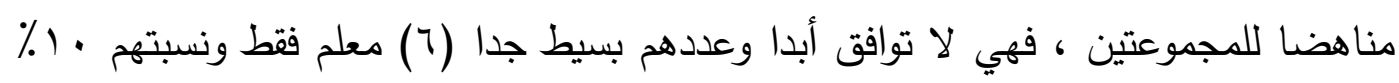
من العدد الكلي لأفراد العينة. 9- يظهر من خلال أجوبة المجموعات الثلاث أن الأولى تؤكد بكل ثقة أن الأساليب المستخدمة

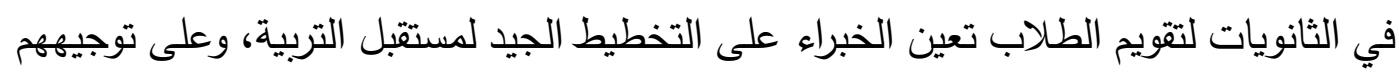

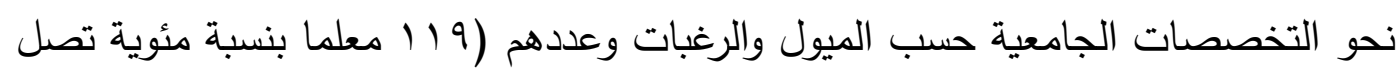
الى ب ٪ \% في موقف قريب منه ذهبت مجموعة ثانية الى ان الاساليب تعين بدرجة متوسطة

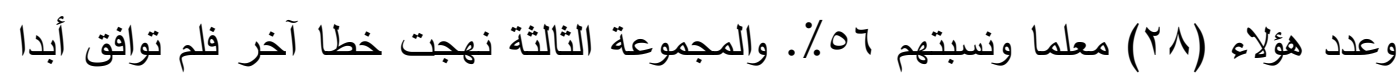
وعددهم (1) معلما ونسبتهم r ب \% من العدد الاجمالي للمستجوبين.

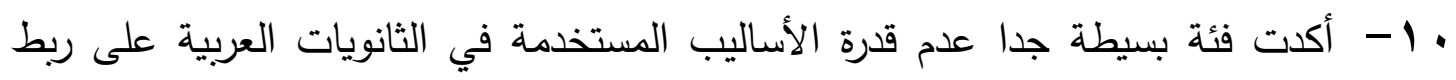

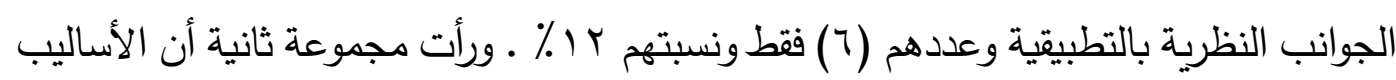


تربط بدرجة متوسطة وعدد هؤلاء كبير ( • م) معلما ونسبتهم عالية تصل الى • ؟ ٪ أكبر نسبة.

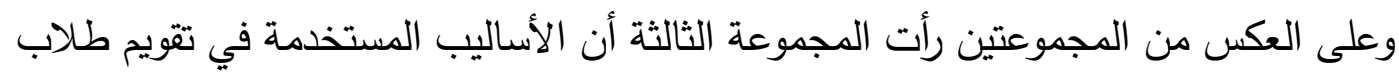

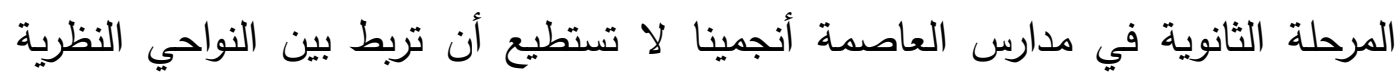

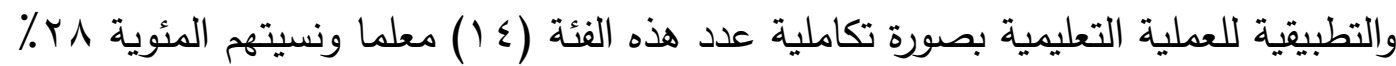

$$
\text { من العدد الكلي للعينة. }
$$

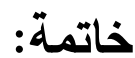

يمثل التقويم التربوي قمة الأدوات القياسية التي من خلالها يمكن الحكم على نجاح التعليم،

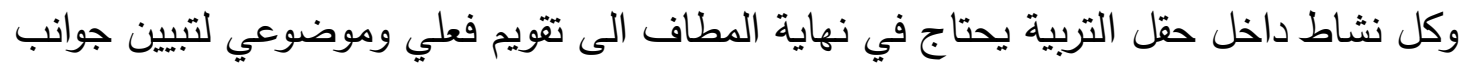

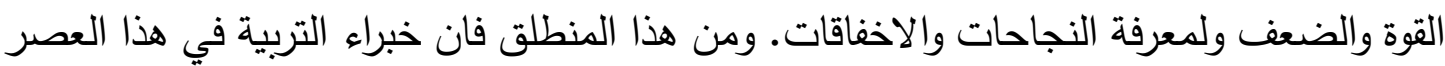

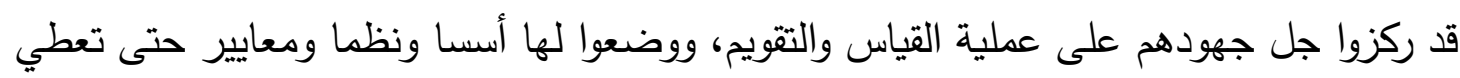

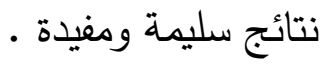

ان المدارس الثانوية العربية في تثاد على غرار المدارس العالمية بحاجة ماسة الى تقويم للأساليب التي يستخدمها المعلمون في نهاية كل سنة دراسية أو مقرر، بل امتد التقويم كالمعتاد ليشمل الوسائل التعليمية كنلك. وتدعيما للمجهودات التي يبذلها الخبراء للوصول الى الحقائق تم لت اجراء هذه الدراسة الميدانية التطبيقية التحليلية والتقويمية في الثانويات العربية بالعاصمة التثادية أنجمينا عبر الاطار العام والنظري الذي اشتمل على التحليل والمناقثة والتعليق على الاجابات الواردة في الاستبانة.

تُعتبر هذه الدراسة الأولى من نوعها في الثانويات العربية، ولذا فقد وجدت قبولا من قبل

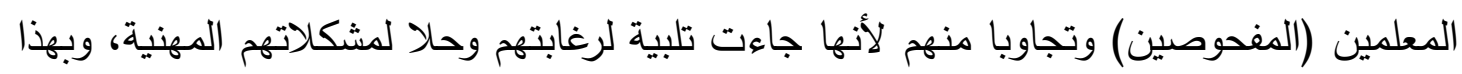

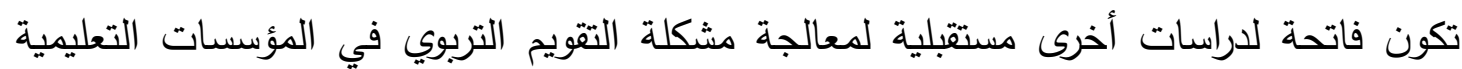
وبالتالي تطويره كي يواكب العصر الحديث.

\section{نتائج الدراسة:}

\section{توصلت الاراسة الى النتائج التالية:.}

- - أساليب التقويم المستخدمة في الثانويات العربية بالعاصمة أنجمينا تقليدية وغير ملائمة

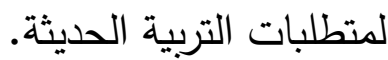

- - التقويم التربوي في المرحلة الثانوية في مدارس تشاد لا يحقق الأهداف التربوية المنشودة الا بنسبة متوسطة. 
- معظم المعلمين في التعليم ما قبل الجامعي في تشاد يعانون من مشكلة وضع الأسئلة وفق الضوابط والمعايير المحددة للتقويم الصحيح.

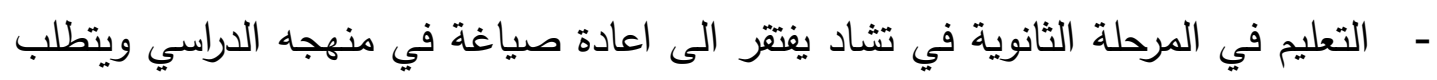
مراجعة فنية لأدوات القياس والتقويم المستخدمة. - أكثر الأساليب المستخدمة في تقوم طلاب المرحلة الثانوية هي الامتحانات التحريرية المعروفة باختبارات التحصيل. - الأساليب التقويمية المستخدمة في الثانويات لها القدرة في ربط الجوانب النظرية بالتطبيقية.

\section{توصيات الدراسة:}

يوصي الباحث في نهاية هذه الدراسة بالتالي:.

- - انشاء وحدة خاصة بالقياس والتقويم بكليات التربية في الجامعات الوطنية التشادية. - - اقامة دورات تدريبية لمعلمي المرحلة الثانوية في تشاد حول الأساليب الحديثة للتقويم التربوي. - تصميم نظام تقويمي حديث يتضمن التخذية الراجعة وتعميمه في مؤسسات التعليم ما قبل - تأهيل المعلمين في معاهد الاعداد، وتدريبهم بواسطة دورات تربوية مكثفة لرفع كفاءاتهم المهنية.

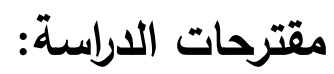

يقترح الباحث موضوعات قابلة للدراسة في المستقبل:

- - - فاعلية أساليب التقويم المستخدمة في كلية العلوم التربوية بجامعة أنجمينا. - - أثر التقويم التربوي في التحصيل الدراسي للطلاب المعلمين بمعاهد اعداد المعلمين. - دورا التقويم التربوي في قياس القدرات العقلية والمعرفية لطلاب الثانويات الحكومية بمدينة البطحى. - واقع استخدام أدوات القياس في مدارس مرحلة الأساس بولاية السلامات جنوب شرق تشاد. - - تقويم مدى المام معلمي التربية الاسلامية بأدوات التقويم في المعاهد الدينية بولاية وداي.

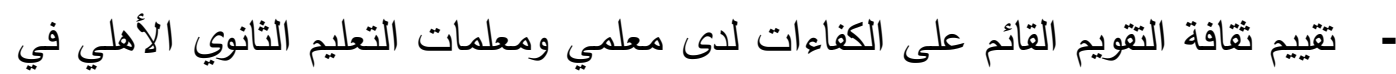
المدارس التشادية.

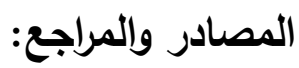

1. ابراهيم أنيس وآخرون(9VY (9V) المعجم الوسيط، القاهرة، ص 11 


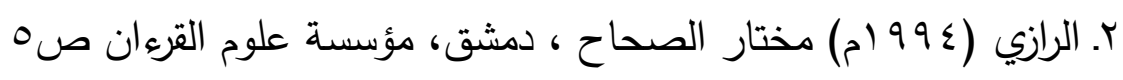

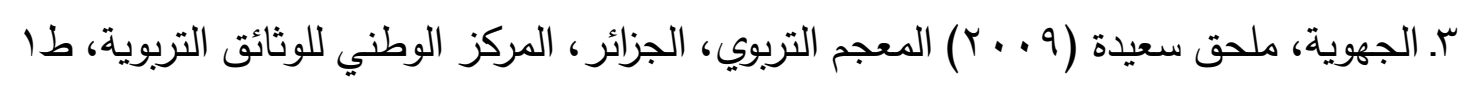
ص9 ז1 ع. رجاء، أبو علاء (l ...rم) النظريات الحديثة في القياس والتقويم وتطوير نظم الامتحانات

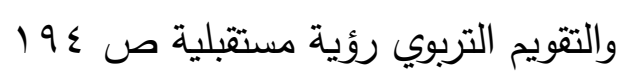

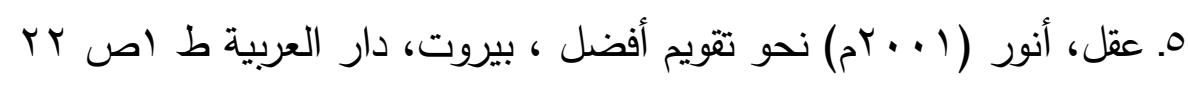

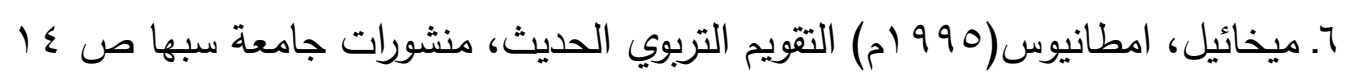

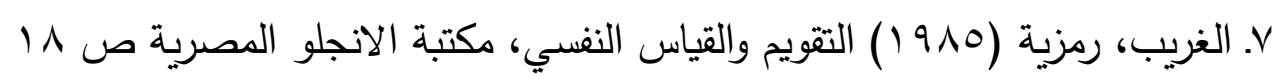

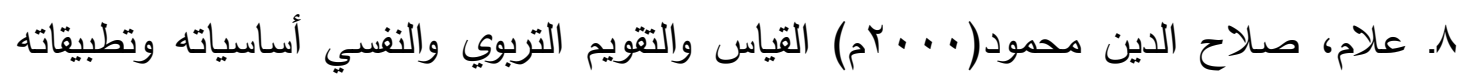

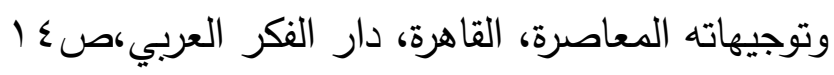

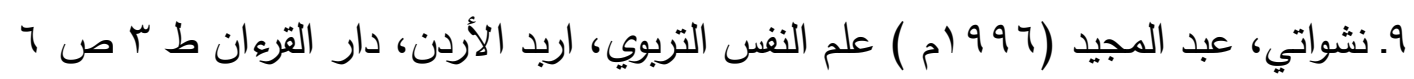

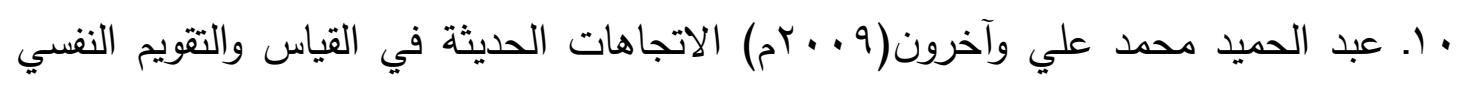

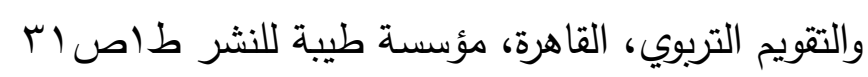
1) ص v r.

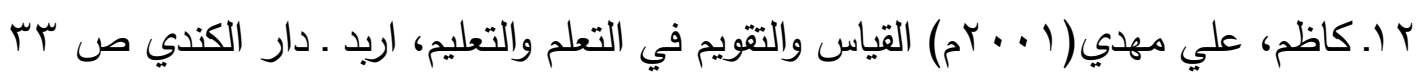

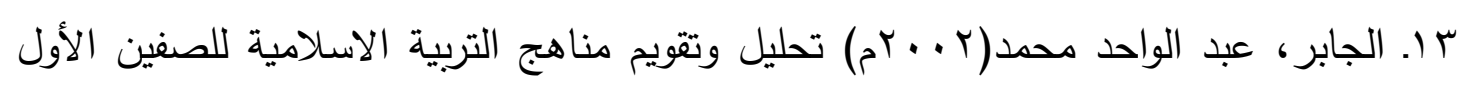
والثاني الثانوي بجمهورية تشاد رسالة دكتوراه (غير منشورة) جامعة أم درمان الاسلامية.

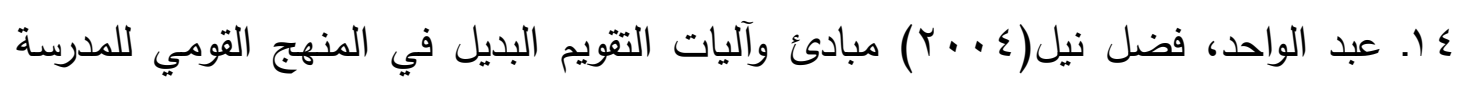

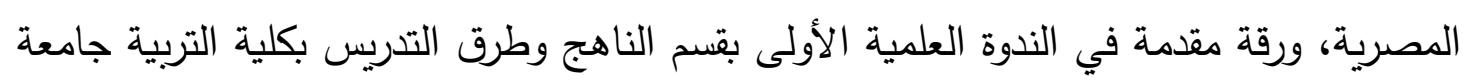
طنطا ص ז

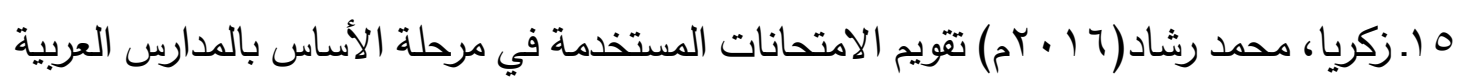
بمدينة أنجمينا رسالة ماجستير في التربية (غير منشورة) قسم أصول التربية كلية العلوم التربوية

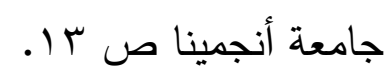

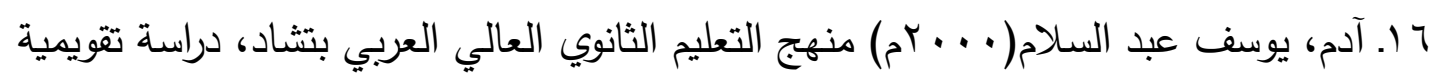

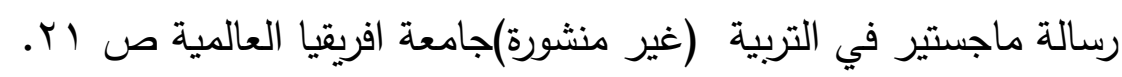

